一五七著原告報會究研事醫堂天順

(0) $=$ 看 病就 $レ$ 動体》古

自其上變 テ

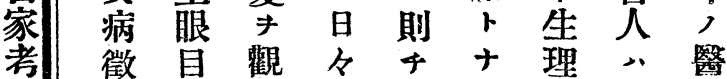

案 $\neq$ 卜 察或 + 的之史

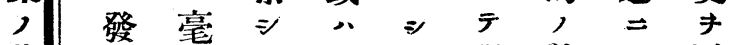

曲露无 $テ$ 時能眼桀由通

光 七 關 其々 $々=$ 况

驗 \#係進單 \#入

眼ル十退純レリ於然ル

鏡 $\Rightarrow \neq$ 劇,

二 先 $\pi$ 易充十脈神工古

就千如 $\neq$ 血り卜經塲 來

テ 病 $\neq$ 探 $\exists$ 其 $+\neq \neq 0$ 驗

初內驗り他り吾窥眼

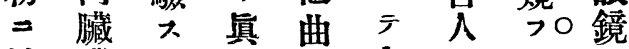

於機几性光之,

厂關モ, 機 $\Xi$ 知得發

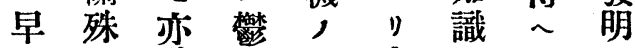

已 $=$ 驗 血 變 出 $=\geqslant=$

二 脊 眼 $=$ 常 $ッ$ 觸又優

其髓 鏡 至

宣

徵岕賴被 テ液 メ 由

キ 䠞 ラ 働他循ン テ 二

搜䏦 + 性觀 環

索臟レノ的ノ八量美

ス、小浮 $\Rightarrow$ 狀驗, 0 事

ル脾 則腫 其况眼㗢 心本 =

モ臟

亦及能り卜觀

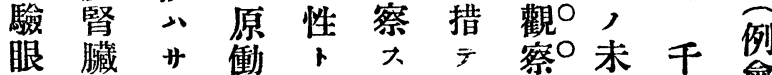

鏡 等 性

(O)

家

考

慗

曲

光

驗

眼

鏡

$\approx$

$\frac{2}{7}$

$\stackrel{ก}{=}$

0
0
0
0
0
0
0
2
0
3
0
0
0
0
0
0

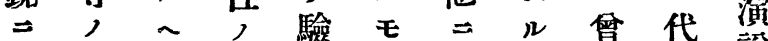

賴病》炎定亦賴

ラ 戀遙症 シ 驗ル得目吉

$\Rightarrow \Rightarrow=$ 眼眼 $\sim \sim$ 擊

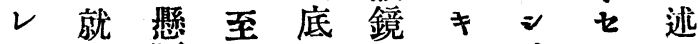

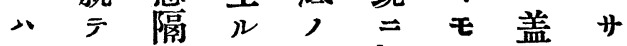

則未 $末$ 種戀賴, シ 几

チ $₹$ 々 化

十他外, 二 \#, 身十

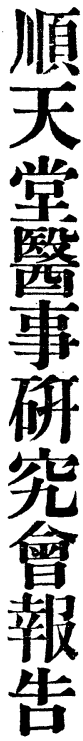

第
百
士
號

每
岳十
十五
日

DI

7I)

Tि 


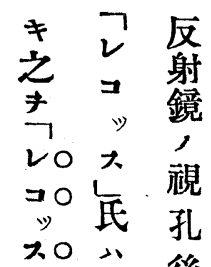

能度後

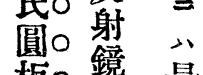

板。鉸 最

系。质 小

統。 後 +

云 眳品

云 轉。牛

連○環

動。狀

$\neq 0$,

to 丽

フ. 0 鏡

ベ○ 架

$\neq 0 \quad p$

圆○”

板

* 之

裝 こ

置 補O

$\approx$ 正。

之 ᄂo

$=\geqslant 0$

補

正 F

レ 裝

$\sim$ 用

大 $三$

ᄂ

嵌 然

入

$\because$ E

及 後

》 $\Rightarrow$
$*$
$y$
$y$

篇 $ン$ ル

メ

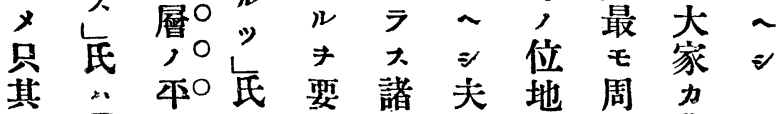

中 $>0$ 面步七他

心

$=$ 子眼 $\Perp$ 變, 科n上

於 ”板○鏡十病如, モ

₹ ガ

> L”發鑑驗術卜用

$\rightarrow$ ₹ 成明

ル 施品 シ

ガシ○之 タ

4 20 斜

, 本○メ彼

一 面O $=$ -

部反。方 千

$\Rightarrow$ 射 形 八

剥鏡。，百

離 $三$ 箱

シ 以内

》 $\bar{F}=$ 一

》憸 裝 年

三 眼 置

力 鏡 直 シ

後 $\ni$

三 構 2 此

八造 モ 驗

鏡 三, 眼

面最士 鏡

”初”只

中心爾 只。

心光線後 >0

視 $夫$ 間 n

孔通王ガ。

*過

穿七》过。
定 眼

大 鏡 進 シ

ル八步つキ

二 特 $へ$ 諧

モ 》三般

亦眼 $又$,

必科》桀器

要,

, 疾最 ᄂ 中

器病大 氏 驗

械 * 貴 カ 眼

$>$ 診 重 驗 鏡

ル衒, 眼

八 $\rightarrow$ 一 鏡 以

古ル要○, テ

來 = 美○發 學

世須 † 明 問

人央》

, モ ト $三$ 最

通缺大 $匚$

曉》入診 美

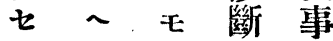

ル力亦及 $=$

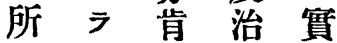

$\Rightarrow \quad$ 示療際

$=n$ 不學上

テ, 當, 最

又要, 範王

吾器言酶 完 


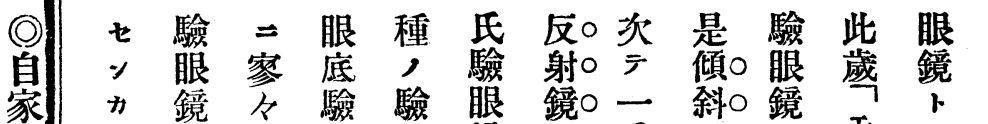

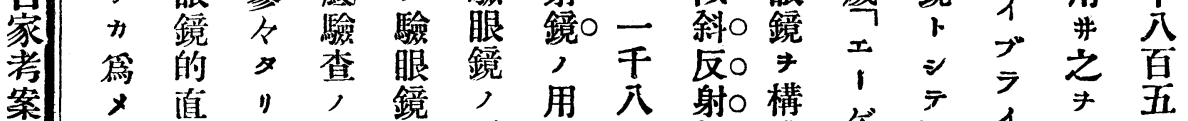

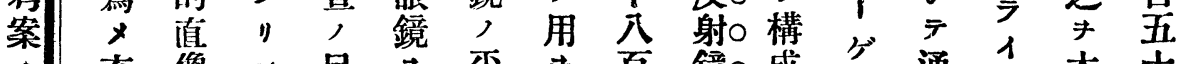

曲离像

光驗 數 法

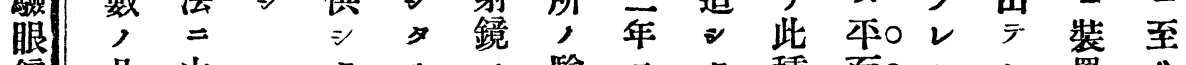

鏡 奤 胄

》 I)

就及曲

七 光

凹 機

面 ₹

ᄀ 測

ン 定

七

大.

F $=$

要

七茲

\# =

其換

驗 三»種面○

今 他, 鏡”

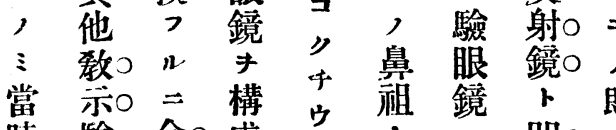

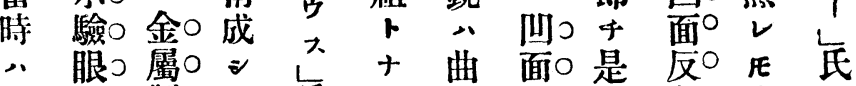

凹。 即 面○

未 鏡○製。其屘大光反口十射此

タ及人翌

$\therefore \sim$ 機

幾

鏡。䴋

曲

, 鏡。

光○雨。面○千面○驗

機○腿。反司 反。

眼 $\neq$

$\neq 0$ 驗。 射 $\circ$ 百 射

鏡 隨

測○眼, 鏡○五 鏡つ

几 發

〜 現

定 鏡。 $夫$ 十

的 意

20等 以四 凸。

\# 7

$\bar{N}$

nO

$\overline{7}$

䮈

亶 交

$\exists$ 眼

1) 鏡

成 八 驗

大 所

ノ○ 棈

年 面。

目。浩之引

的

曲

$\Rightarrow$ 》 凸о

光

驗○ル 面○ン ト

機

㱍

眼 モ レั デ キ

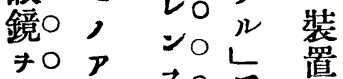

三 最

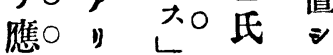

乇

用。然

確

シ0リ装 ᄀ平。

實

$>0 卜$ 置 9 面

$=$

ルO踓

補

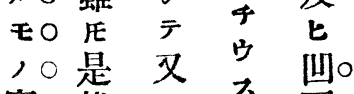

正

二換

必 三

要 $\bar{~}$

缺・斜

頗查

驗ル,

眼 過 目

鏡大的

$\neq=\Rightarrow$

構 $=$ 始

造 テ メ

三不

ク $=$ タ 便 中o

カ嵌古り孔。

ラ 入

H

ル

モ

, 得

秘 $=\geqslant 0$

为 穿。

1) 故如

$1 \Rightarrow$

$=$ ح

$\Rightarrow \neq$

ブ爾 ルo

1 後 以。

1 間 面 ${ }^{\circ}$

七成面。

氏 + 射

驗》鏡。 


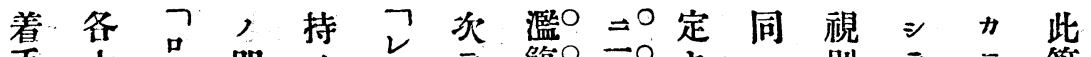

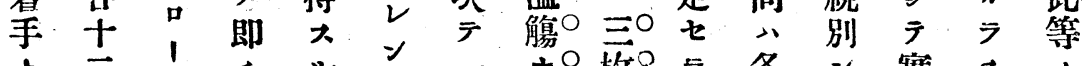

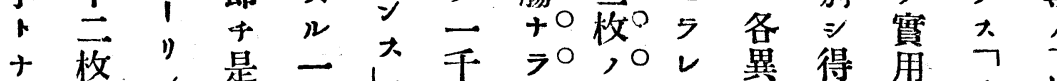

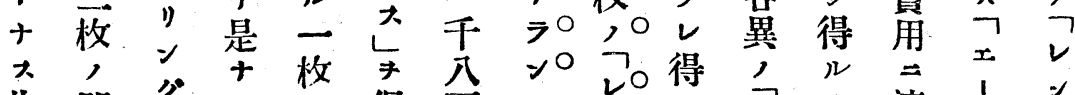

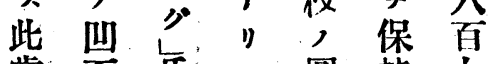

歳面 代圆持 七

$\geqslant$ 及 $\rightarrow$ 板 $ォ$ 古

兄手 改云年

プ 面 公 メ 枚

瓜 直

亦 $>$ 七

孪共四

凸 ま 年

× 保 $\Rightarrow$

持 始

光

ᄂ $ル テ$

氏 一自

驗 枚 家

眼,

鏡 圓 驗

$\Rightarrow$ 板 眼

殆

$++=$

相 三 改

同 $\Rightarrow$ 正

シ リ

キ之加

器 ま へ

械同 乙

キ 氏 コ

構

成 驗

夕枚

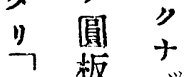

》。板

to + 底

プO シ 凹

芨当 次

ㄴ.

ம0

エ

ツ○ル ᄂ

ケ○瓜 系

巵口各統

, 二 至

曲 十 政

光驗枚 シ

眼。, テ

鏡○叫—

面

及面叫

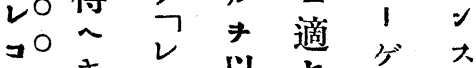

以 $\neq$ v 以

, 0 ,

齐其努氐范

氐故 $\neq$ 度 何羷射

圓 ${ }^{\prime}=$ 速 ト 眼 鏡 板○开定十鏡,

*0口 $\Rightarrow$ a レノ 哯

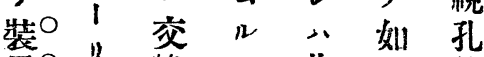

置○”換, 曲》後

シ0 比事光或

タ○グ較實機 心於

リ氐 $\approx \Rightarrow$ 兵

是 $\approx$ 基测 $\neq$ 容

盖一以

活 $干$ 法却》

曲八最几心シ 且

光百无一或

機七確, 定 “速

計實十っ之川

测○年 $=レ$ 補 $ま=$

定 二 補 $心$ 正湈 交

七其正十 + 入換

ン○自大リ オ

カ○的ル此劣 ッ

需 $\neq$ 所等 方等 レ

メ○澾ノノ光得

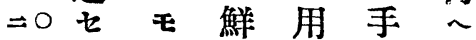

驗つン，明井數キ

眼つが

三 眼 压

タ 鏡 系

リ改 統

但 正 $\neq$

シ, 改

此第 メ

テ 匕 面

通凸レ

鏡○零 示 二 最要 如

垷面 ン

七 $v \rightarrow$

ラ $レ$ ᄂ

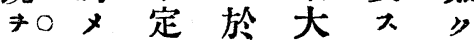

構○白○フケ鮮へ 裝

成○家。 $ル$ 明 $\neq$ 置

大

\&

ルま口

$=10,0 \Rightarrow$ 些 $=$ 器

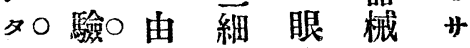

ルO眼テ $テ$, 底小ル

等 一 テ

モ保面

ノ○鏡○制異 ま 概 
Fint

著原告䞢會究研事醫堂天順

自

七

自 $=$

家 邓

案 カ

, 篇

曲 $x$

光 單

驗 =

眼 普

\begin{tabular}{c|c} 
鏡 通 \\
二 反
\end{tabular}

就 射

鏡

側

*

奵

離

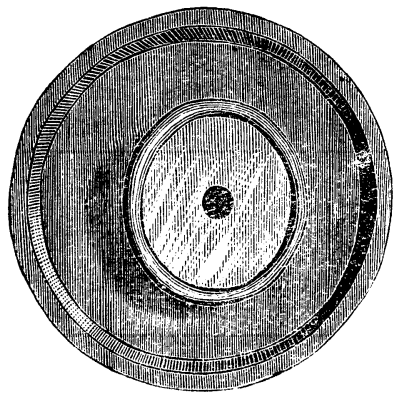

砧

殆像 兵

、查、

甘 $=\begin{gathered}\text { H } \\ -1\end{gathered}$

度充 少

傾, 分皆文分光

斜光 “别光”, 改

ま線此

テ與便区得面り シ

之へ

キ而避鏡 キ

五.
ン驗品+ナ+

裝ジ $シ=$ 過

置 三同要 $ア$ 小

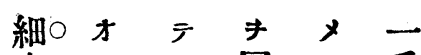

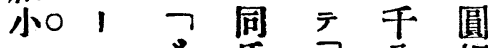

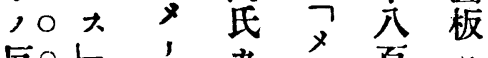
反Oட, 射 $\therefore$ 驗 ! 七 㻁 鏡○只祭上十轉 $=0$ ᄂ 鏡 ᄂ 永 シ0!系改系年儿 テ ○ 統 正統 二, 右○ $\exists 0$ 則第 則 $\Rightarrow$ V 》0 昏 ト 至 左○驗 ”、ト》” 二。眼新 + 新 $^{\text {ᄂ }}$ ᄂ 名了鏡 式、式。 轉。”㱖, 開擦 シ ○改番歲番了會 倠 而メ號 一號セ

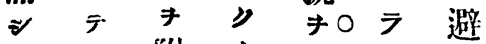
テ直附十附○と午 二0像 シ プ シ タ ン 十0 驗 \& ᄂ >0 N 度查几氏 几0第点 , ○, モ $匚$ 五 傾用, 亦 斜 $=*$ 三 70 或 金 キ○ 供 構十 ᄂ。眼 有○七成志录。科環 成○學 一

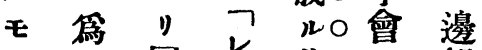
> $x$ 同 $v$ 曲 $=$ 緣 F十年 7 光○於 $=$ 雖 䍀之五○ボし驗○テ 由

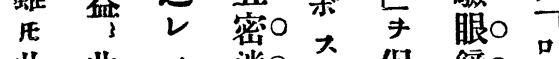
此曲 二 迷○古保鏡○口

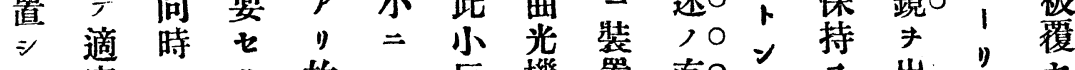

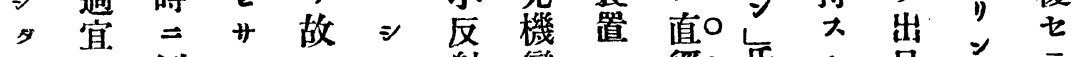
リ, 倒ル $\approx$ 射戀

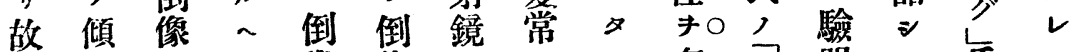
二斜及皮像像, , 有只眼, 氏 倒 $夫$ 七 像得㨁香查便定即师犬゙ 


\section{號六十三百第告犎會究研事醫堂天順 六五七}

迷 $\Rightarrow$ 斜度。次之反及

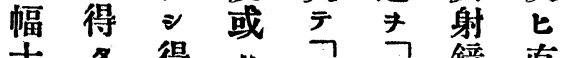

十 得 $⿻$ 吕吕鏡 直

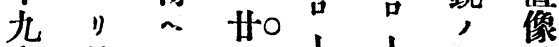

密是 ₹五。! ! ”如驗

迷 則 *度。”” ”查

₹千以 $10 \%$ 光 $=$

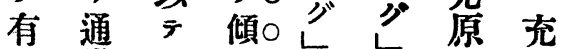

七常更斜比氐, 分

”

之1 0 之 $\neq 0$ 区眼地 光

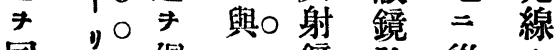

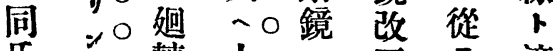

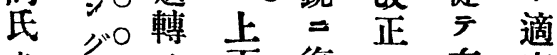

カ2゙刃 卡復, 右宜

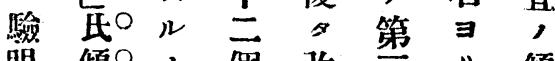

眼 傾○，個改等”傾

鏡 斜必, 正左斜

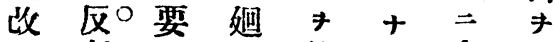

正 射 $千$ 轉 施 2 之與

, 鏡○”點 $\approx$ 至

第

四三像於雨轉》

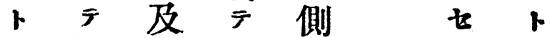

十通

大曉倒 $夫$ 切氐

七像固離一未

亏驗定 $シ$ カ

香 $シ \bar{z}$ ᄀ

） $\Rightarrow$ 殆 0 \#

用》等

モ井此 10 , ,

, 厂度平不

=充射行品便交

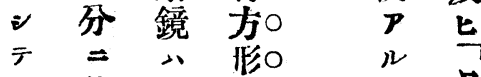

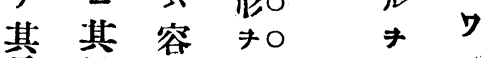

長百易得 免

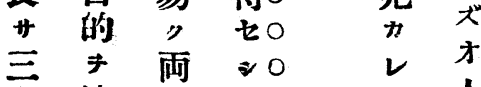

干達岗側

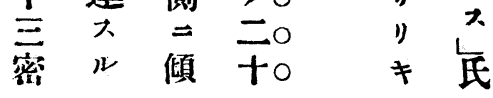
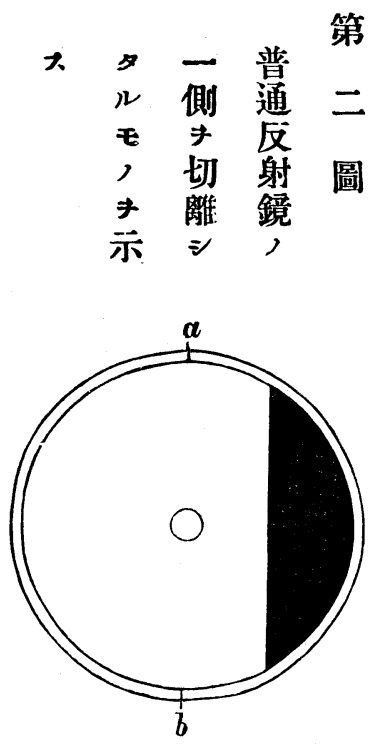


\section{七五七著原告報會究研事醫堂天順}

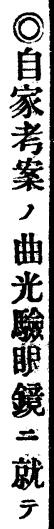

$$
\begin{aligned}
& \text { ，傾り 》方離，普 } \\
& \text { 示斜 } ン n \text { 形 } \approx \text { 兩通四 } \\
& \text { 大 反 グ } \\
& \text { 射 ᄂ } \square+4 \neq \text { 平圖 } \\
& \text { 鏡 氏 } 1=\text { 行 切鏡 }
\end{aligned}
$$

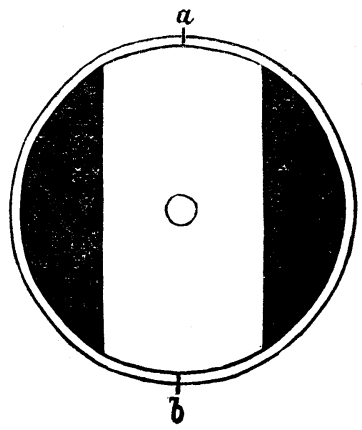

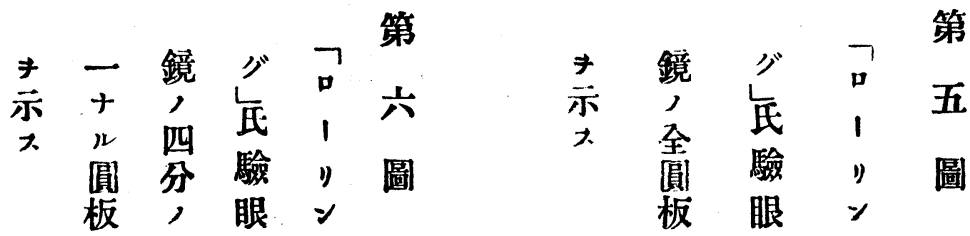

七
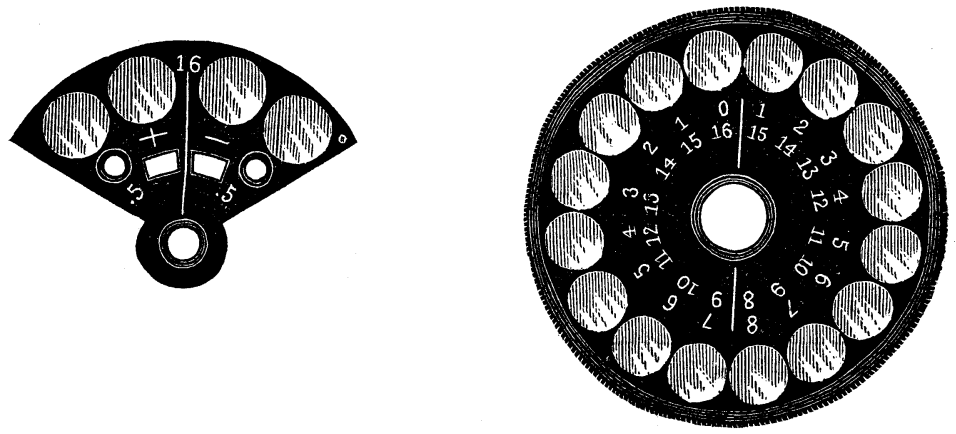
號六十三百第告報會究研事醫堂天順入五七

力面板n, 故一十内數 ᄀ 叫 $\Rightarrow$ 器差 $\Rightarrow$ 共 $大$ 列字 $ン$ 充 面九奋械, 此曲此, 即 $、 コ$ 分し

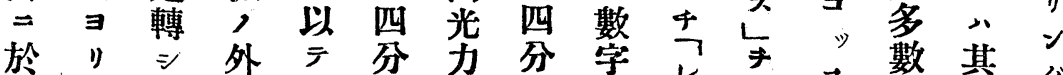

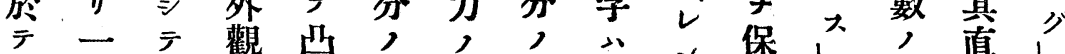

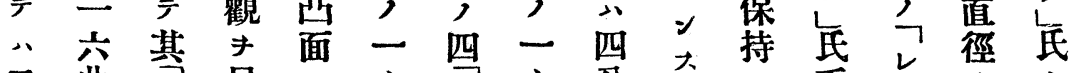
二 典 四光

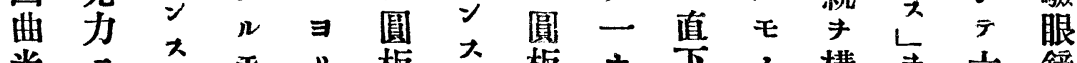

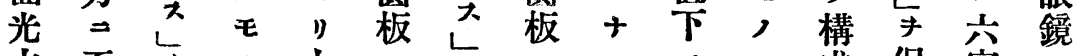

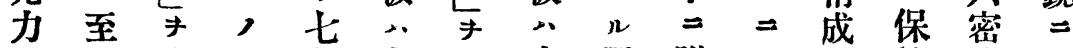
$=\lll$ 全卜曲之保值圆附 $三 \equiv$ 持迷就

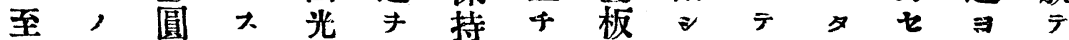

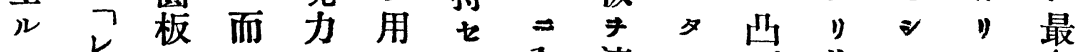

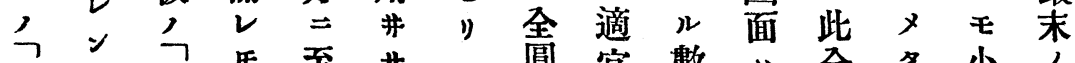
レ、レ 氏 至 サ 圓宜數》全 ン ᄂ 大寻示非尘持字板

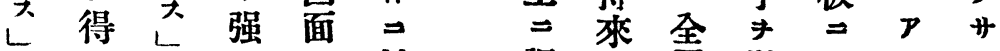

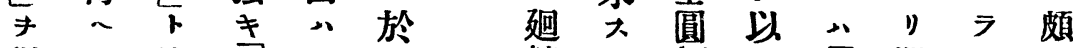

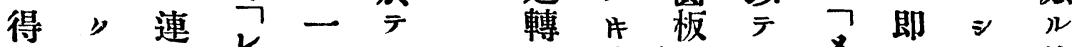

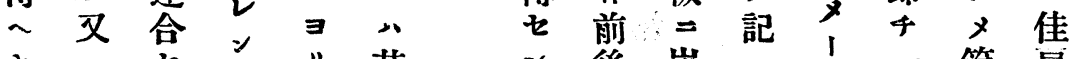
キ二七共

+ 六

1曹。 $\Delta$ 曲方 光 $v$ 要 光 $=$ 力八刀力趗 ヨ凸 几上轉 ”面填 至 以. 上八 八於平 凹り テ 面 一 小 $\Rightarrow$ 六此 7 驗 於曲四保 眼 厂 光 分持 鏡 八力, 力八

$\equiv=-n-$ 至十單曲 曲 $\pi$ 二 光 光凹圆 + 力

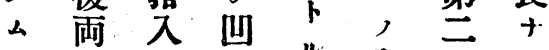

只的面

* ン \& 得 $ン 几$ 赤統板機, - $、 、$ 字 $=1$, = $\neq>1$ 少全

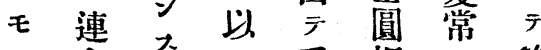
, 合 こテ番板 $ま$ 第 二ヨ, 記號, 最一

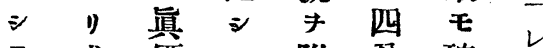
二成價 》附分確

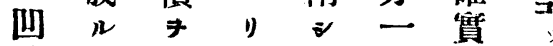
出價示而 $タ+=$ 各值シシ心ル補

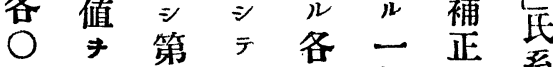
、示三第十板七 系 五大列 一共卜 1 , 統 及 $千$ 即列對 $\neq$ ガ 七, 千, , 以雼

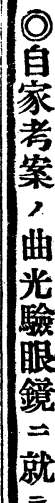


九五七著原告報會究研事醫堂天順

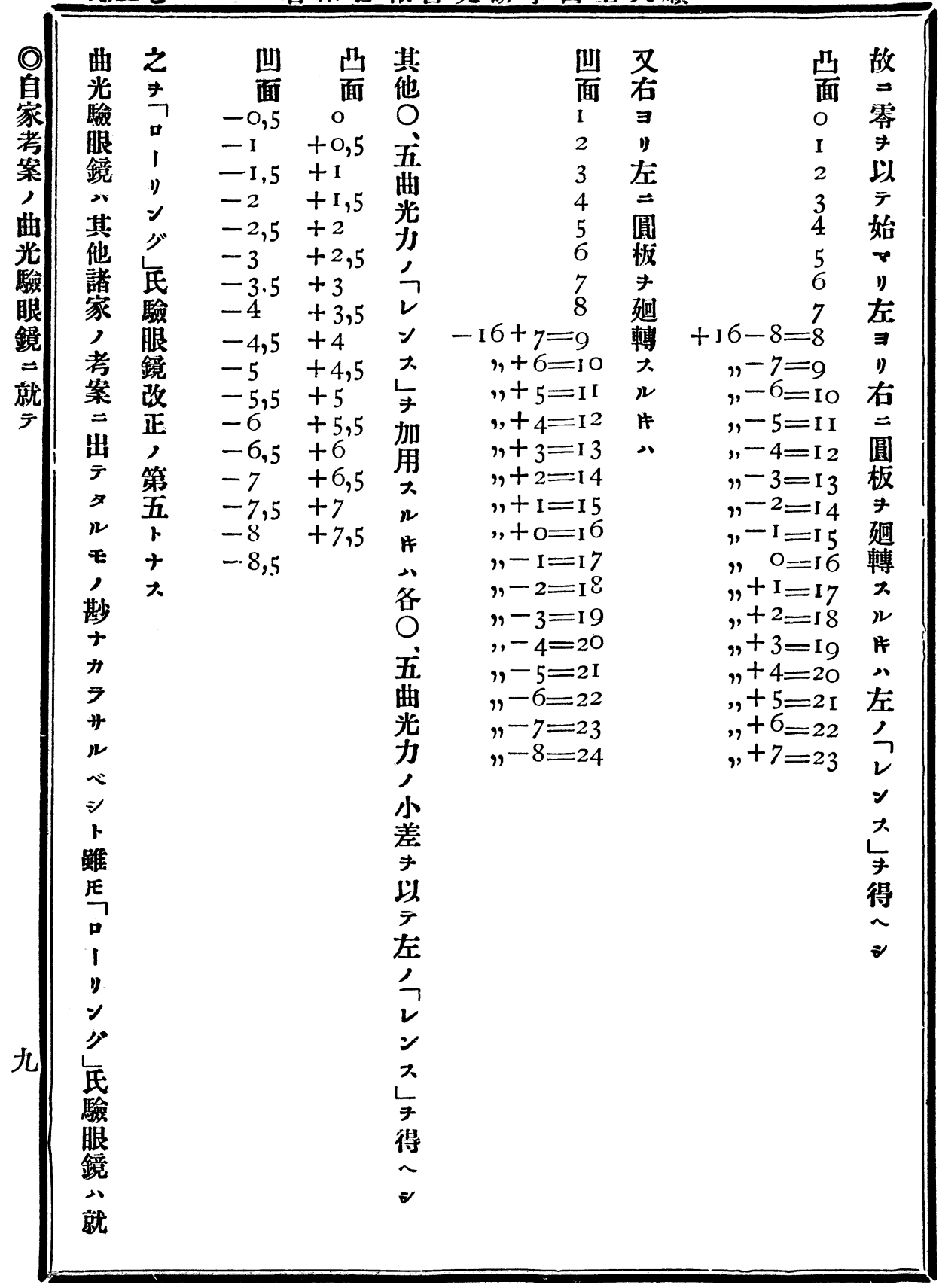



ソ゚ ギ○ 欲

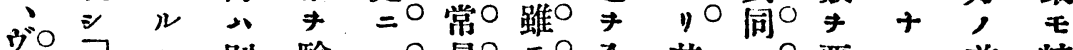

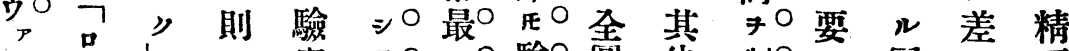

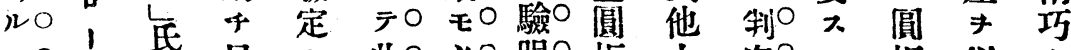

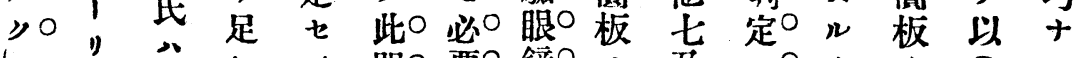

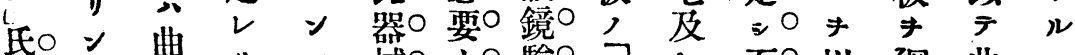

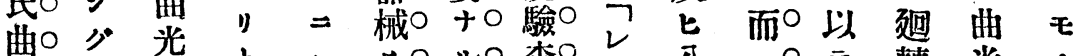

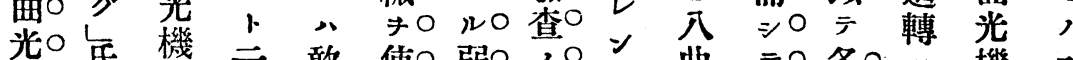
匬 眼○驗 测 $\cdots$ 用○度○實

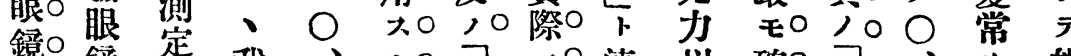

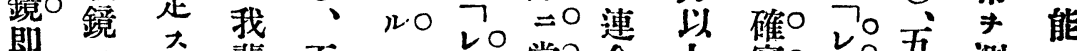

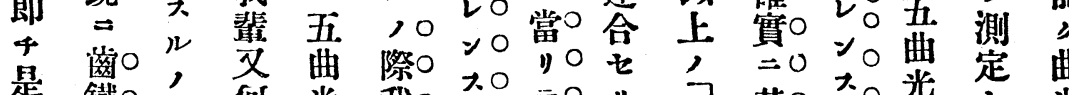

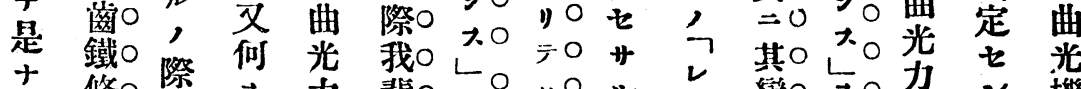

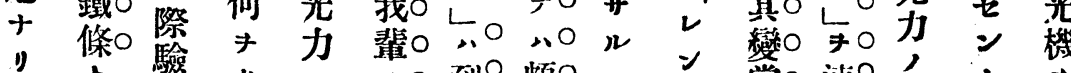

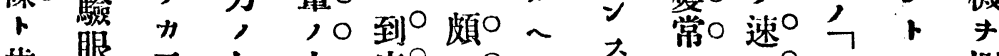

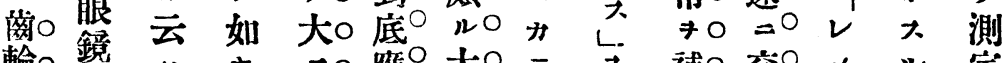

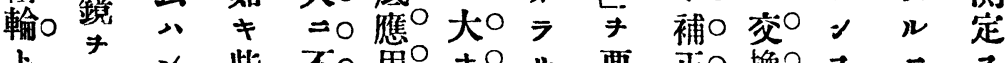
1 * 辳 唯細 便O

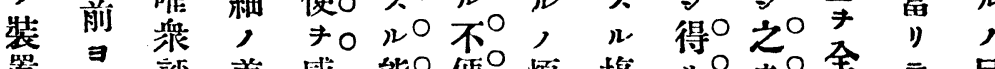

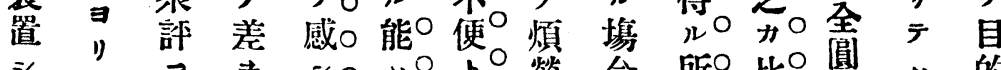

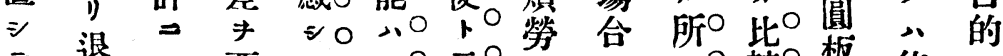

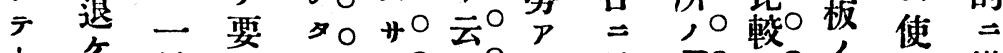
少

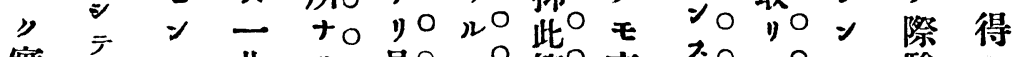

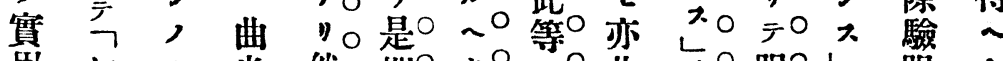
用 $レ$ 光 然即 $n^{\circ}$, 此 $\neq 0$ 眼 $ᄂ$ 眼

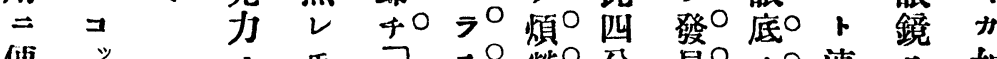

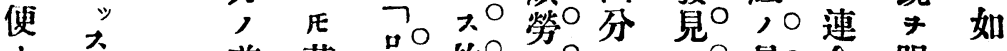
+ 差若 10 故 > $^{\circ}$, 20 最合眼

ラ 代

$=$ 圆

$\times$ 板

F $=$ 》0

以 論 ソ0 曲 ${ }^{\circ}$ 實 $^{\circ}+$

几○ 鮮○ せ

前 然

刃

v迴

テ 者

之 $P$

7 轉

* リ邸 *0 細 板

グ○ 光 00 ル

«明叶

$\exists \quad$ y

口 $\mathrm{O}$ 最度。ル

1)

$10 \%$

1) 7

定 曲

大 光

ル機

\section{驗 驗}

眼查。几O阿

鏡。 大O $\rightarrow 0$ 輞
モ๐ 二。〜退 踓

難於。カ

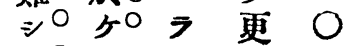

ト 0 n $\#$ \#

․․ 微○ 四 五. ル 細。, 分 曲 


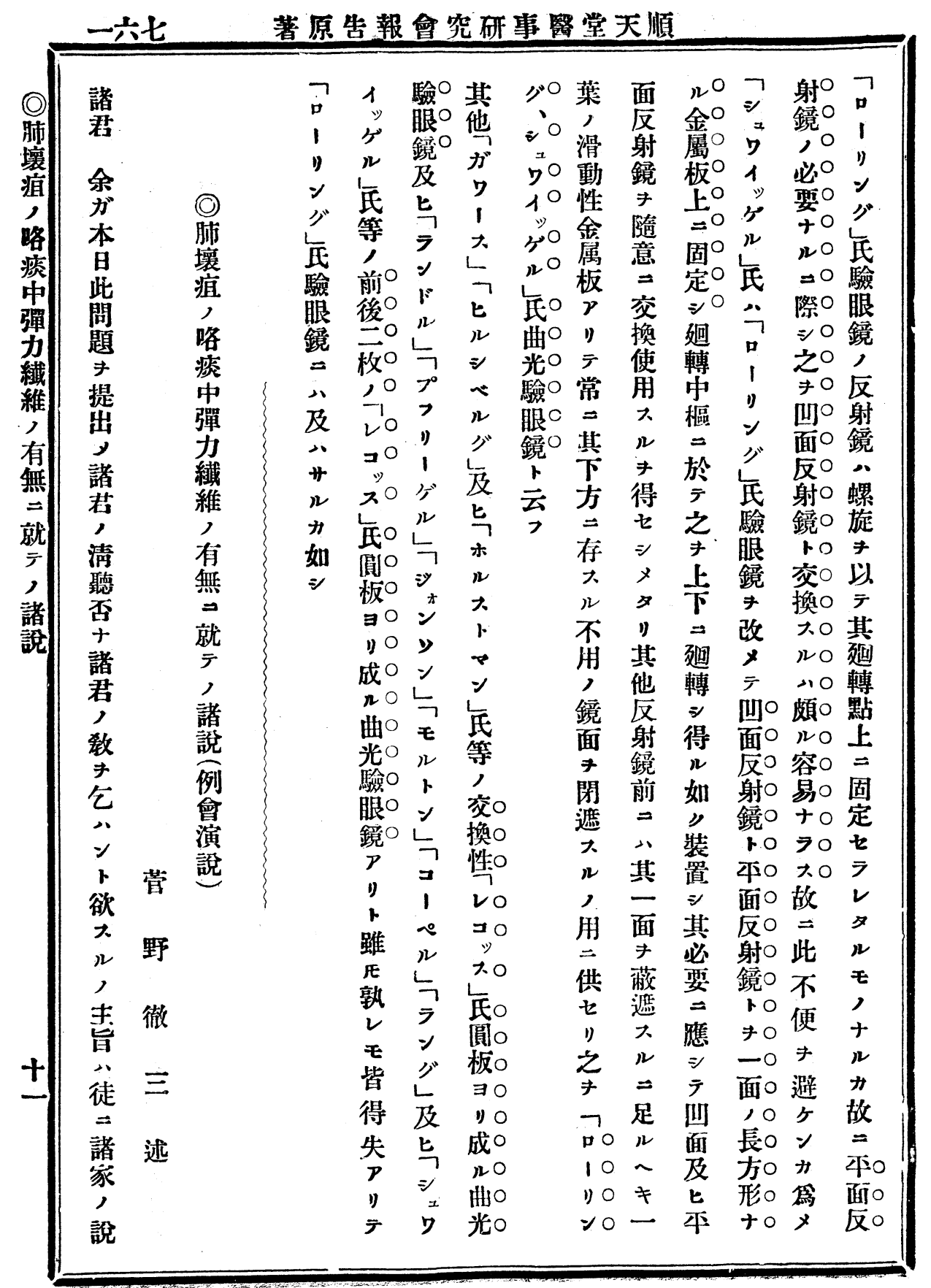

